\title{
The P/E Ratio And Profitability
}

Wan-Ting (Alexandra) Wu, University of Massachusetts Boston, USA

\begin{abstract}
This paper examines the relation between the forward price-to-earnings (P/E) ratio and profitability. Consistent with the theoretical predictions of Ohlson and Zhan (2006), this paper finds a $U$-shaped relation between the forward P/E ratio and return on equity (ROE). Besides, firms with high P/E ratios tend to have lower ROE in the subsequent years, and their ROE is very volatile and wide-distributed. Using the GSCORE from Mohanram (2005), this paper separates winners from losers among high P/E firms. Firms with high GSCORE yield higher earnings growth, sale growth, ROE, and excess stock returns in the following years.
\end{abstract}

Keywords: P/E Ratio; Profitability; Return on Equity; GSCORE

\section{INTRODUCTION}

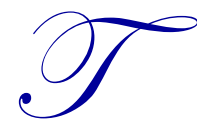

his paper examines the relation between the price-to-earnings (P/E) ratio and profitability. Ohlson and Gao (2006) theoretically predict a U-shaped relation between the forward P/E ratio and return of equity (ROE). They propose that firms with very high or very low ROE have higher forward P/E ratio than other firms. The goal of this paper is to provide empirical evidence to their proposition, which has not been tested in prior literature. This paper also analyzes the distribution of subsequent ROE in firms with different forward $\mathrm{P} / \mathrm{E}$ ratio and examines the possibility to distinguish winners from losers in the high forward P/E stocks.

The $\mathrm{P} / \mathrm{E}$ ratio plays a pivotal role in both academic research and investment practices and it has been found to reflect the market's expectation of future growth and is associated with firm risk (Zarowin, 1990; Thomas \& Zhang, 2006; $\mathrm{Wu}$, 2013). This ratio is related with the value/glamour anomaly (Basu, 1977, 1978; Jaffe et al., 1989) and has been used by money managers to form investment strategies. The P/E ratio is used to estimate the cost of equity capital (Easton, 2004) and is also heavily used by financial analysts to justify their stock recommendations. Bradshaw (2002) finds that $76 \%$ of the sell-side analysts cited the P/E ratio as a justification for their stock recommendations. This frequency is two times of the next mostly used variable - 'Growth'- which is cited in $37 \%$ of analysts' reports. Despite the crucial role of the P/E ratio, the extant research has not fully explored its relation with profitability. The only exception is Ohlson and Gao (2006) who use theoretical models to predict the relation between the P/E ratio and return on equity. However, their theoretical predictions have not yet been empirically tested. This paper fills the gap in literature by utilizing empirical data to test the relations between the P/E ratio and ROE. The evidence in this paper enhances our understanding about the consequences of equity valuation.

In order to test the relation between the P/E ratio and ROE, the sample is first sorted into ten deciles based on ROE. The differences in the P/E ratio across the deciles are tested. Consistent with the proposition of Ohlson and Gao (2006), the results show that the forward P/E ratio has a U-shaped relation with realized ROE in the subsequent one, two, or five years. A regression analysis shows that among deciles 1 and 6 , there exists a negative relation between the forward P/E ratio and ROE and their relation becomes positive among deciles 7 to 10 . The next analysis examines the distribution of ROE for firms with different forward P/E ratios. This paper shows that firms in the highest P/E quintile have a wider distribution of ROE than firms in other quintiles. The large standard deviation and interquartile range (Q3-Q1) of ROEs indicate that high P/E firms have more volatile ROE than other firms. The wide distribution of ROE in the high P/E firms implies that it is risky to invest in such firms because their ROE in the subsequent years could be very high or very low. Although the market expects high P/E firms to have high future growth, the outcome can be unpleasant because some firms achieve low profitability in subsequent years. The wide distribution of ROE in the high P/E firms also suggests that separating winners from losers is desirable to help investors earn excess returns. Using the GSCORE developed in Mohanram (2005) - a measure tailored for growth 
firms based on financial statement analysis, this paper successfully differentiates winners from losers in high P/E stocks. The results show that firms with a higher GSCORE generate higher sales growth, earnings growth, and ROE than firms with a lower GSCORE in the subsequent two and five years. A long-short strategy based on GSCORE also earns significantly positive returns in the subsequent two years.

This paper contributes to the literature in several ways. First, this paper provides the first empirical evidence to the predictions of Ohlson and Zhan (2006). The theoretical U-shaped relation between forward P/E ratio and ROE is supported by empirical data analysis. Second, this paper shows that Mohanram (2005)'s GSCORE can be used for high P/E stocks to separate winners from losers so that excess returns can be earned. The results in this paper give insights to the investment community regarding how to identify firms with strong future earnings growth, sales growth, ROE, and stock returns.

\section{LITERATURE REVIEW AND HYPOTHESIS DEVELOPMENT}

\section{Literature Review}

Valuation models, such as the Gordon Growth model and the Ohlson and Jeuttner-Nauroth (OJ) model, suggest that the $\mathrm{P} / \mathrm{E}$ ratio is a function of expected earnings growth and expected rate of return. Specifically, the theories predict that $\mathrm{P} / \mathrm{E}$ ratio is positively correlated with expected growth and negatively correlated with expected rate of return. Some studies find that that $\mathrm{P} / \mathrm{E}$ ratio is better explained by forecasted growth than realized growth (Beaver \& Morse, 1978; Zarowin, 1990; Thomas \& Zhang, 2006). Thomas and Zhang (2006) show that replacing the trailing P/E ratio with the forward P/E ratio yields results that are more consistent with the theoretical predictions.

Prior literature has examined how the P/E ratio can be used to estimate the cost of equity capital (Easton, 2004), to explain stock prices (Liu et al., 2002, Schreiner \& Spremann, 2007; Kim \& Ritter, 1999), and to predict future earnings (Ou \& Penman, 1989; Fairfield, 1994; Penman, 1996; Chan et al., 2003; Wu, 2013). It is a wellknown phenomenon that the P/E ratio is related with the value/glamour anomaly (Basu, 1977, 1978; Jaffe et al., 1989). Prior studies show that an investment strategy which longs low $P / E$ stocks and shorts high $P / E$ stocks yields significant positive returns. In the investment community, the $\mathrm{P} / \mathrm{E}$ ratio is also heavily used by financial analysts to justify their stock recommendations. Bradshaw (2002) finds that $76 \%$ of the sell-side analysts cited the P/E ratio as a justification for their stock recommendations.

Compared to the trailing P/E ratio, the forward P/E ratio divide stock price by forecasted earnings and thus is less affected by nonrecurring earnings. Prior literature demonstrates that forward-looking earnings are more valuerelevant than historical earnings (Dechow et al., 1999; Kim \& Ritter, 1999; Liu et al., 2002; Yee, 2004). Liu et al. (2002, p. 138) conclude that 'they [the forward earnings] should be used as long as earnings forecasts are available.' Consistent with this argument, there exists evidence that the forward $\mathrm{P} / \mathrm{E}$ ratio explains stock prices better than other historically based financial ratios. Such results are robust for the U.S. and European markets and IPO settings (Liu et al., 2002; Schreiner \& Spremann, 2007; Kim \& Ritter, 1999). Wu (2013) also find that the forward P/E ratio predicts future earnings growth better than the trailing $\mathrm{P} / \mathrm{E}$ ratio.

\section{Hypothesis Development}

The hypothesis on the association between the forward P/E ratio and profitability is based on the models in Ohlson and Gao (2006). From the OJ model, Ohlson and Gao (2006) derive the following model:

$p_{0} / x_{1}=k_{1}+k_{2} /$ roe $_{1}$

where $p_{0} / x_{1}$ is the forward P/E ratio, $k_{1}=1 /(R-\gamma)$ and $k_{2}=(1-\gamma) /(R-\gamma) \cdot \gamma$ is the growth rate of residual income. The relation between the forward P/E ratio and ROE depends on the sign of $k_{2}$, which in turn depends on whether $\gamma$ is greater or less than 1. (i) If $\gamma \geq 1$, then $k_{2}<0$, which implies a positive relation between the forward $\mathrm{P} / \mathrm{E}$ ratio and $r_{0} e_{1}$, with the forward P/E ratio bounded below by $1 / r$ ( $r$ is the cost of equity capital). (ii) If $\gamma<1$, then, $k_{2}$ $>0$, which implies a negative relation between the forward P/E ratio and $r o e_{1}$, with the forward P/E ratio bounded below by $1 / r$. Therefore, Equation (1) implies a U-shaped relation between the forward P/E ratio and roe $e_{1}$. 
Hypothesis: The forward P/E ratio has a U-shaped relation with ROE.

\section{SAMPLE}

The sample is drawn from Compustat annual data files, CRSP monthly return file, and the IBES summary file. Analysts' consensus EPS forecasts are converted to a diluted basis using the I/B/E/S dilution factors. Consistent with prior studies (e.g., Thomas \& Zhang, 2006), this paper requires the earnings-to-price ratio to be bounded between zero and one to exclude outliers. Firms are required to have stock prices no less than $\$ 2$ and firms in the financial and utility industry (i.e., firms with SIC 6000-6999, 4900-4999) are excluded from the sample. The main sample consists of 55,104 firm-year observations with no missing data for the major variables.

In order to calculate the forward $\mathrm{P} / \mathrm{E}$ ratio, this paper obtains analysts' consensus (median) earnings forecast for the coming fiscal year in mid-April of each year. The timing is consistent with Liu et al. (2002) and is so chosen to ensure that most analysts and investors have received and processed the previous fiscal year's financial reports. ${ }^{1}$ The forward P/E ratio is calculated as stock price divided by the consensus (median) earnings forecast for the coming fiscal year. ${ }^{2}$ The profitability in the following ten years is examined. The Appendix shows the definitions of the main variables in this study.

Table 1: Descriptive Statistics

\begin{tabular}{|c|c|c|c|c|c|c|c|}
\hline \multicolumn{8}{|c|}{ Panel A: Characteristics of the Sample } \\
\hline & \multirow{2}{*}{$\begin{array}{c}\text { mean } \\
19.519\end{array}$} & std & $\min$ & $\mathrm{q1}$ & median & q3 & $\max$ \\
\hline$F P E_{t}$ & & 11.821 & 7.935 & 11.773 & 15.629 & 22.422 & 54.635 \\
\hline$R O E_{t+1}$ & 0.091 & 0.193 & -0.918 & 0.052 & 0.108 & 0.162 & 0.680 \\
\hline$R O E_{t+5}$ & 0.071 & 0.258 & -1.478 & 0.040 & 0.104 & 0.159 & 0.812 \\
\hline$R O E_{t+10}$ & 0.079 & 0.273 & -1.493 & 0.040 & 0.105 & 0.165 & 0.990 \\
\hline$X F I N_{t}$ & 0.152 & 0.344 & -0.237 & -0.007 & 0.055 & 0.169 & 2.131 \\
\hline CEXP $P_{t}$ & 0.352 & 0.347 & 0.034 & 0.151 & 0.244 & 0.415 & 2.158 \\
\hline Payout $_{t}$ & 0.250 & 0.492 & 0.000 & 0.005 & 0.072 & 0.321 & 3.483 \\
\hline$B M_{t}$ & 0.574 & 0.496 & -0.099 & 0.281 & 0.475 & 0.732 & 3.377 \\
\hline Size $_{t}(\$ M)$ & 3213.960 & 9311.280 & 22.397 & 163.966 & 472.476 & 1663.920 & 63907.650 \\
\hline$L E V_{t}$ & 3.056 & 3.441 & -3.816 & 1.501 & \multirow{2}{*}{$\begin{array}{c}2.048 \\
432.795\end{array}$} & 2.999 & 19.941 \\
\hline$S T(\$ M)$ & 2562.190 & $\begin{array}{l}6588.650 \\
\end{array}$ & 12.078 & 129.888 & & 1539.750 & 44287.110 \\
\hline \multicolumn{8}{|c|}{ Panel B: Firm Characteristics by Forward P/E ratio } \\
\hline \multirow{2}{*}{\multicolumn{2}{|c|}{ - }} & Low & 2 & $\mathbf{3}$ & \multirow{2}{*}{\multicolumn{2}{|c|}{4}} & High \\
\hline & & 9.492 & 12.899 & \multirow{2}{*}{$\begin{array}{c}16.216 \\
0.113\end{array}$} & \multirow{2}{*}{\multicolumn{2}{|c|}{21.564}} & 41.198 \\
\hline \multicolumn{2}{|l|}{$R O E_{t+1}$} & 0.104 & 0.111 & & & & 0.039 \\
\hline \multicolumn{2}{|l|}{$R O E_{t+5}$} & 0.069 & 0.089 & 0.097 & \multicolumn{2}{|r|}{0.093} & 0.044 \\
\hline$R O E_{t+10}$ & & 0.093 & 0.087 & 0.106 & & 0.103 & 0.066 \\
\hline$R \& D_{t}$ & & 0.012 & 0.017 & 0.026 & & 0.039 & 0.069 \\
\hline$C_{C E X P_{t}}$ & & 0.322 & 0.304 & 0.326 & & 0.376 & 0.491 \\
\hline$X F I N_{t}$ & & 0.143 & 0.115 & 0.127 & & 0.163 & 0.285 \\
\hline Payout $_{t}$ & & 0.219 & 0.266 & 0.264 & & 0.246 & 0.191 \\
\hline$B M_{t}$ & & 0.779 & 0.601 & 0.494 & & 0.420 & 0.417 \\
\hline Size $_{t}(\$ M)$ & & 2769.800 & 2948.360 & 3351.180 & & 3630.500 & 3020.670 \\
\hline$L E V_{t}$ & & 4.600 & 3.603 & 2.783 & & 2.385 & 2.251 \\
\hline$S T(\$ M)$ & & 3210.140 & 2878.000 & 2703.290 & & 2175.650 & 1494.050 \\
\hline
\end{tabular}

Note: See Appendix for variable definitions.

Table 1 summarizes the descriptive statistics of the sample. Panel A provides an overview of the sample's firm characteristics. The mean and median of forward P/E (FPE) ratio is 19.519 and 15.629, respectively. The mean/median of book-to-market $(B M)$ ratio is $0.574 / 0.475$. The statistics of these financial ratios are similar to those in Liu et al. (2002), except the mean of $F P E$ is a bit higher in this paper. The majority of the sample has positive $R O E$ in the subsequent years. Panel B presents the firm characteristics of each forward P/E quintile formed in April

${ }^{1}$ The results are robust when the forward P/E ratio is calculated based on analysts' earnings forecasts in June.
${ }^{2}$ Results are qualitatively similar when two-year-out EPS forecasts are used to calculate the forward P/E ratio.

Copyright by author(s); CC-BY 
of each sample year. Among the five quintiles, firms in the highest FPE quintile have the largest R\&D, capital expenditures, and external financing, but the lowest dividend payout rate, which suggests that such firms tend to have large investment in activities that drive future growth. It is likely that these growth-driving activities induce the market to expect high future growth from these firms and thus drive the stock valuation higher. However, these firms have lower ROE than other firms in the subsequent years (their mean $R O E_{1}, R O E_{5}, R O E_{10}$ are $0.039,0.044$, 0.066 , respectively). The unpleasant performance in profitability indicates that high P/E firms do not perform as well as expected. This finding is consistent with $\mathrm{Wu}$ (2013) who finds that high $\mathrm{P} / \mathrm{E}$ firms report worse earnings growth than other firms.

\section{ANALYSIS}

\section{P/E Ratio and Profitability}

Based on Ohlson and Gao (2006), this paper predicts a U-shaped relation between the forward P/E ratio and the subsequent realized ROE. In order to test the hypothesis, the sample is first sorted into ten deciles based on $R O E_{t+k}(k=1$ to 10$)$. The differences in the forward P/E ratios between deciles are tested. Figure 1 graphs the mean forward $\mathrm{P} / \mathrm{E}$ ratio for each $R O E_{t+1}$ decile. Consistent with the prediction, a $\mathrm{U}$-shaped relation exists between forward $\mathrm{P} / \mathrm{E}$ ratio and ROE. Apparently, firms with disappointing profitability in year $t+l$ tend to have high forward $\mathrm{P} / \mathrm{E}$ ratio in year $t$. The mean forward $\mathrm{P} / \mathrm{E}$ ratio for firms in the lowest $R O E_{t+l}$ decile is above 35 , which is the highest among the ten deciles.

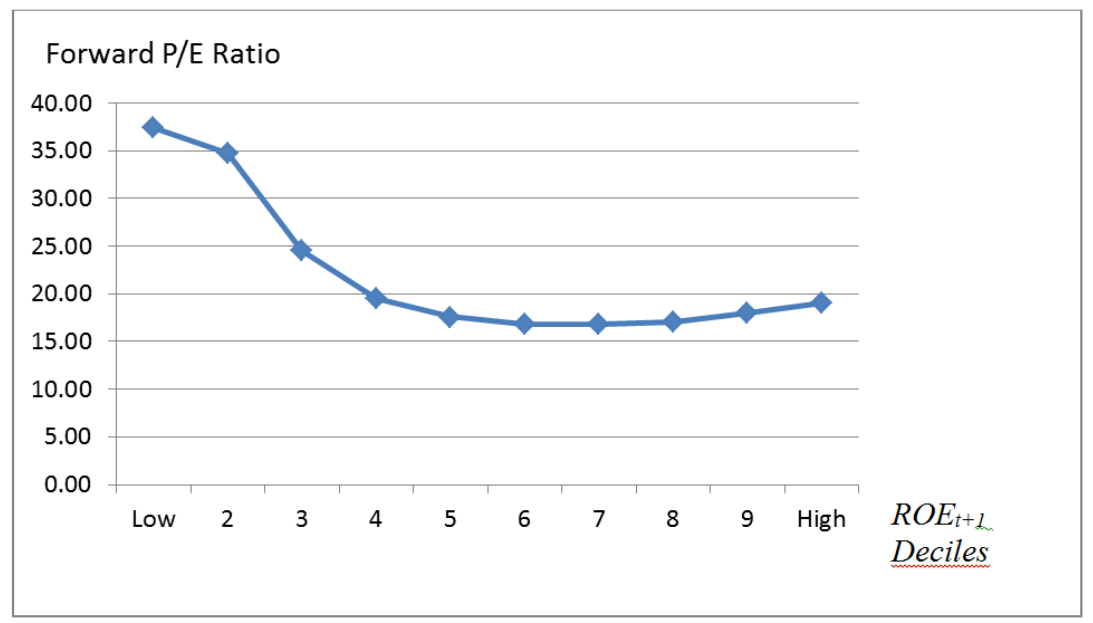

Figure 1: Relation between the Forward P/E Ratio and $\mathrm{ROE}_{t+1}$

Table 2 reports the statistical tests of the U-shaped relation between the forward P/E ratio and ROE. Panel A shows that when deciles are formed based on $R O E_{t+l}$ (i.e., $k=1$ ), firms in the lowest $\mathrm{ROE}_{t+1}$ decile have negative $\mathrm{ROE}_{t+1},(-0.264)$, which is the lowest profitability among the whole sample. However, these firms have the highest forward P/E ratio in year $t\left(F P E_{t}=37.387\right)$. The differences in $F P E_{t}$ between any two adjacent $R O E_{t+l}$ deciles are significantly different from zero, except for the difference between deciles 1 and 2 and the difference between deciles 6 and 7. Firms in deciles 6 and 7 have the lowest forward P/E ratio in year $t$ (16.827 and 16.844, respectively). Panel A also shows that firms in deciles 8, 9, and 10 have larger ROE than firms in deciles 6 and 7, and their FPE are higher as well $(17.030,18.018$, and 19.032, respectively). Overall, among deciles 1 to 6 , there is a negative relation between FPE and ROE, but their correlation becomes positive among deciles 7 to 10 . Similar results are found for the two-year $(k=2)$ and five-year $(k=5)$ horizons. However, the U-shaped relation is not obvious for a horizon of ten years. ${ }^{3}$ When $k=10$, deciles 6 and 7 still have the lowest the forward P/E ratio in year t, but their forward P/E ratios are not significantly different from those of the adjacent deciles.

\footnotetext{
${ }^{3}$ Unreported results show that the U-shaped relation between the forward P/E ratio and ROE becomes less obvious when horizon extends beyond seven years.
} 
Panel B of Table 2 shows the results when ROE is regressed on the FPE. The analysis is implemented for deciles 1 to 6 and for deciles 7 to 10, individually, to catch the difference in the relation between FPE and ROE in these two groups. Consistent with the results in Panel A of Table 2, ROE has a negative relation with FPE in deciles 1 to 6, but it has a positive relation with FPE in deciles 7 to 10 . For deciles 1 to 6 , the estimated coefficient of $F P E$ varies from -0.0062 for $R O E_{t+5}$ to -0.00164 for $R O E_{t+10}$. The coefficients are all significant at the $1 \%$ level. In contrast, the estimated coefficient of $F P E$ is positive for regressions in deciles 7 to 10 (i.e., 0.00051 for $R O E_{t+5}$ to 0.00072 for $\left.R O E_{t+1}\right)$. Overall, the regression analysis supports the findings in Figure 1 and Panel A of Table 2, all of which suggest a U-shaped relation between the forward P/E ratio and ROE.

\section{Separate Winners from Losers in the High Forward P/E Firms}

While the market expects firms with high forward P/E ratio to have high future growth, the results in Tables 1 and 2 indicate that such firms tend to have lower profitability in the subsequent years. In order to better understand the relation between the forward P/E ratio and the subsequent profitability, this paper sorts the firms into five quintiles based on the forward P/E ratio and examines the distribution of ROE in each quintile.

Table 2: Forward P/E Ratio and Realized Profitability in Subsequent Years

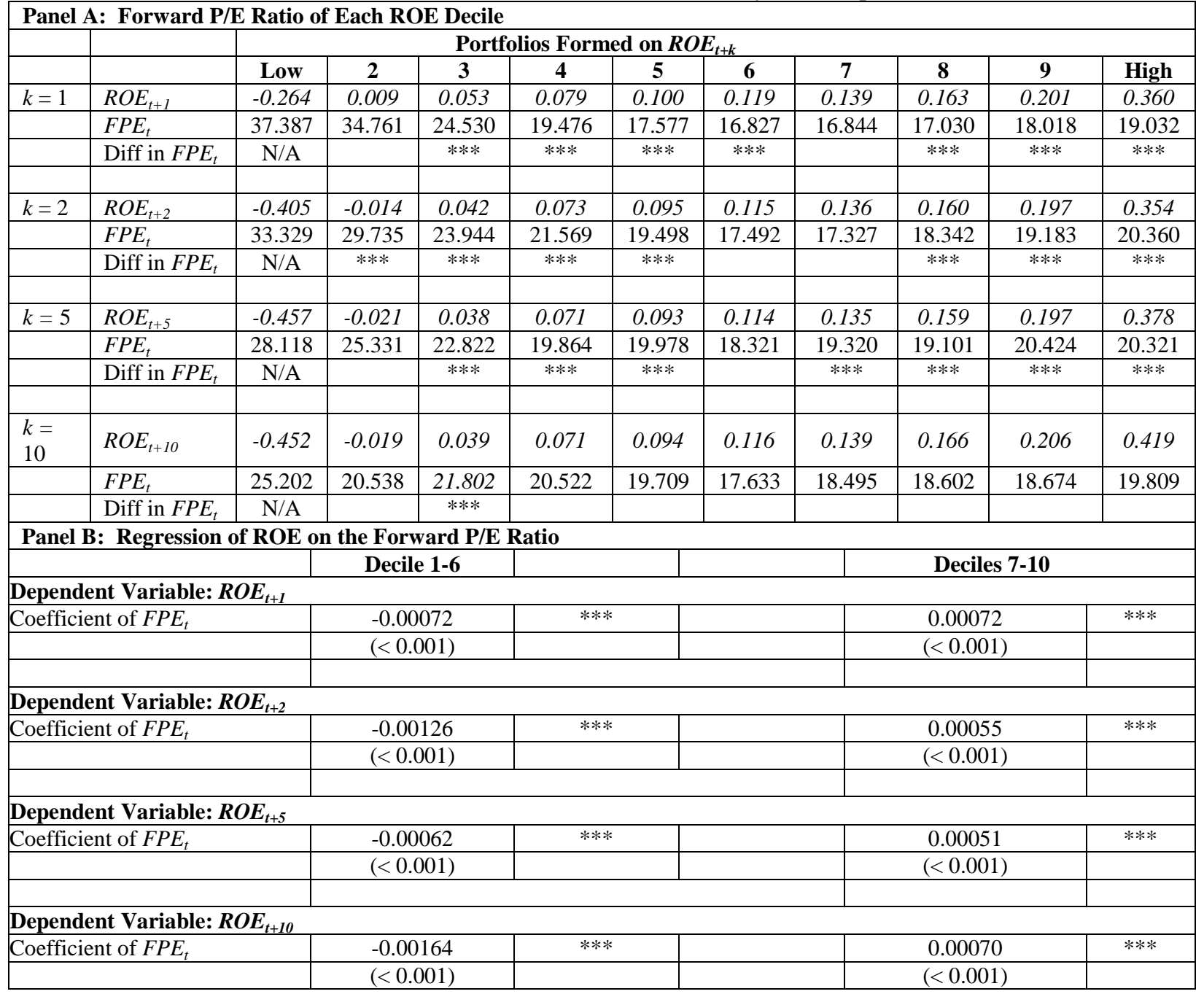

Note: In Panel A, differences in the forward P/E ratio (FPE) between any two adjacent deciles are tested using two-tailed Wilcoxon test. Panel B reports the estimated coefficients in the regressions of $\mathrm{ROE}_{\mathrm{t}+\mathrm{k}}$ on $\mathrm{FPE}_{\mathrm{t}}$ in deciles 1-6 and deciles 7-10, individually. The p-value is shown in parenthesis. $* * *, * *, *$ stand for being significant at $1 \%, 5 \%$, and $10 \%$, respectively. 
Panel A of Table 3 shows that firms in the highest forward P/E quintile have the lowest mean of ROE in year $\mathrm{t}+1$. The mean of their $R O E_{t+1}$ is 0.039 , which is significantly lower than the ROE of firms in the lowest forward P/E quintile (0.104), even though the latter firms are conventionally viewed as financially distressed firms. The distribution analysis also points out the wide distribution of ROE for firms with high P/E ratio. For example, the standard deviation of $R O E_{t+1}$ for firms in the highest forward P/E quintile, 0.223, is larger than other firms. The interquartile range $(\mathrm{Q} 3-\mathrm{Q} 1)$ of their $R O E_{t+1}, 0.139$, is also higher than other firms. The results of $R O E_{t+5}$ and $R O E_{t+10}$ in Panels B and C of Table 3 also indicate that firms in the highest P/E quintile have the lowest profitability in the subsequent years and their profitability is widely distributed and has high volatility.

Given the wide distribution of profitability in the highest forward P/E quintile, it is desirable to have a method that separates winners from losers to help investors earn excess returns. This paper utilizes the GSCORE from Mohanram (2005) - an index tailored for growth firms - to achieve this goal. Based on financial statement analysis, Mohanram (2005) creates an index GSCORE which effectively separates winners from losers among low book-to-market stocks.

Table 3: Distribution of ROE in Each Forward P/E Quintile

\begin{tabular}{|c|c|c|c|c|c|c|c|c|}
\hline \multicolumn{9}{|c|}{ Panel A: Distribution of $\mathrm{ROE}_{\mathrm{t}+1}$} \\
\hline $\begin{array}{l}\text { P/E Ratio } \\
\text { Quintiles }\end{array}$ & Mean & Std & Min & Q1 & Median & Q3 & Max & Q3-Q1 \\
\hline Low & 0.104 & 0.216 & -3.533 & 0.072 & 0.118 & 0.166 & 1.529 & 0.094 \\
\hline 2 & 0.111 & 0.175 & -2.257 & 0.072 & 0.116 & 0.161 & 1.529 & 0.089 \\
\hline 3 & 0.113 & 0.184 & -3.533 & 0.072 & 0.120 & 0.170 & 1.529 & 0.098 \\
\hline 4 & 0.108 & 0.186 & -2.257 & 0.059 & 0.114 & 0.174 & 1.529 & 0.115 \\
\hline High & 0.039 & 0.223 & -2.257 & -0.003 & 0.059 & 0.137 & 1.529 & 0.139 \\
\hline \multicolumn{9}{|c|}{ Panel B: Distribution of $\mathrm{ROE}_{t+5}$} \\
\hline $\begin{array}{c}\text { P/E Ratio } \\
\text { Quintiles }\end{array}$ & Mean & Std & Min & Q1 & Median & Q3 & Max & Q3-Q1 \\
\hline Low & 0.069 & 0.277 & -7.959 & 0.048 & 0.102 & 0.148 & 2.151 & 0.100 \\
\hline 2 & 0.089 & 0.231 & -3.341 & 0.056 & 0.106 & 0.154 & 2.151 & 0.098 \\
\hline 3 & 0.097 & 0.243 & -3.341 & 0.060 & 0.116 & 0.167 & 2.151 & 0.108 \\
\hline 4 & 0.093 & 0.260 & -3.533 & 0.052 & 0.116 & 0.173 & 2.151 & 0.121 \\
\hline High & 0.044 & 0.292 & -3.341 & 0.007 & 0.085 & 0.152 & 2.151 & 0.145 \\
\hline \multicolumn{9}{|c|}{ Panel C: Distribution of $\mathrm{ROE}_{t+10}$} \\
\hline $\begin{array}{c}\text { P/E Ratio } \\
\text { Quintiles }\end{array}$ & Mean & Std & Min & Q1 & Median & Q3 & Max & Q3-Q1 \\
\hline Low & 0.093 & 0.267 & -3.341 & 0.057 & 0.106 & 0.160 & 1.768 & 0.103 \\
\hline 2 & 0.087 & 0.240 & -3.341 & 0.052 & 0.104 & 0.159 & 1.768 & 0.107 \\
\hline 3 & 0.106 & 0.238 & -3.341 & 0.059 & 0.115 & 0.177 & 1.768 & 0.117 \\
\hline 4 & 0.103 & 0.276 & -3.533 & 0.058 & 0.119 & 0.179 & 1.768 & 0.121 \\
\hline$\overline{H i g h}$ & 0.066 & 0.324 & -7.959 & 0.027 & 0.101 & 0.161 & 1.768 & 0.134 \\
\hline
\end{tabular}

The eight fundamental signals used by Mohanram (2005) are as follows. Each signal is defined based on a comparison with industry performance.

$G 1=1$ if $R O A_{t} \geq$ industry median $R O A_{t}$ and 0 otherwise;

$G 2=1$ if $C F R O A_{t} \geq$ industry median $C F R O A_{t}$ and 0 otherwise;

$G 3=1$ if $C F R O A_{t} \geq R O A_{t}$ and 0 otherwise;

$G 4=1$ if $V A R R O A_{t} \leq$ industry median $V A R R O A_{t}$ and 0 otherwise;

$G 5=1$ if $V A R S G R_{t} \leq$ industry median $V A R S G R_{t}$ and 0 otherwise;

$G 6=1$ if $R \& D_{t} \geq$ industry median $R \& D_{t}$ and 0 otherwise;

$G 7=1$ if $C E X P_{t} \geq$ industry median $C E X P_{t}$ and 0 otherwise;

$G 8=1$ if $A D_{t} \geq$ industry median $A D_{t}$ and 0 otherwise.

These signals are composed of three categories of information to predict a firm's future performance. $G 1$ to G3 are signals related with a firm's profitability in earnings or cash flows. CFROA is cash flow return on assets, measured as cash from operations divided by average total assets. $G 4$ and $G 5$ signal a firm's stability in performance 
and are related with investors' native extrapolation. VARROA (VARSGR) calculates the volatility of quarterly ROA (sales growth) over the past four years. $G 6$ to $G 8$ are signals related with accounting conservatism. A company's $\mathrm{R} \& \mathrm{D}$, capital expenditures, or advertising activities may depress current earnings but may boost future growth. GSCORE is the sum of these eight signals.

In this analysis, firms in the highest forward P/E quintile are sorted into nine portfolios based on their GSCORE (from zero to eight). Table 4 reports the subsequent sales growth, earnings growth, ROE, and stock returns of these nine portfolios. As the results indicate, sales growth, earnings growth, and ROE in the following two and five years all show a monotonic relation with GSCORE, except for firms with GSCORE $=0$. When the two lowest portfolios $(0,1)$ are grouped as the low group and the highest three portfolios $(6,7,8)$ are grouped as the high group, there exist substantial differences in the two-year earning growth, sales growth, and ROE between the high and low groups (the differences are 1.211, 0.034, 0.130, respectively). The inferences are similar for the five-year earnings growth, sales growth, and ROE. The results in returns analysis indicates that firms with a higher GSCORE have higher stock returns than firms with a lower GSCORE. An investment strategy, which takes a long position on the high group and a short position on the low group, earns a raw return of $16.40 \%$ and a size-adjusted return of $12.30 \%$ in the subsequent two years. In sum, the GSCORE developed by Mohanram (2005) is able to distinguish winners from losers among high forward P/E stocks. Firms with a higher GSCORE generate stronger earnings growth, sales growth, ROE, and stock returns in the subsequent years.

Table 4: Growth, ROE, and Returns to an Investment Strategy Based on GSCORE for High Forward P/E Firms

\begin{tabular}{|c|c|c|c|c|c|c|c|c|c|}
\hline \multirow[b]{3}{*}{ GSCORE } & \multirow[b]{3}{*}{$\mathbf{N}$} & \multicolumn{6}{|c|}{ Growth and ROE } & \multicolumn{2}{|c|}{ Returns } \\
\hline & & \multicolumn{2}{|c|}{ GR_E $\mathbf{E}_{\mathbf{t}+\mathbf{K}}$} & \multicolumn{2}{|c|}{ GR_S $\mathbf{S}_{\mathbf{t}+\mathbf{K}}$} & \multicolumn{2}{|c|}{$\mathbf{R o e}_{t+K}$} & \multirow[b]{2}{*}{$\begin{array}{c}\text { Raw } \\
\text { Return }\end{array}$} & \multirow[b]{2}{*}{$\begin{array}{c}\text { Size-adj } \\
\text { Return }\end{array}$} \\
\hline & & $k=2$ & $k=5$ & $k=2$ & $k=5$ & $k=2$ & $k=5$ & & \\
\hline 0 & 110 & -0.025 & 1.368 & 1.154 & 1.423 & -0.003 & -0.103 & $3.40 \%$ & $-10.20 \%$ \\
\hline 1 & 516 & -0.321 & 1.519 & 1.11 & 1.418 & -0.040 & 0.011 & $2.20 \%$ & $-10.30 \%$ \\
\hline 2 & 1561 & 0.024 & 1.412 & 1.112 & 1.420 & -0.022 & -0.016 & $10.50 \%$ & $-7.40 \%$ \\
\hline 3 & 1924 & 0.434 & 1.646 & 1.113 & 1.451 & 0.003 & 0.018 & $19.80 \%$ & $0.10 \%$ \\
\hline 4 & 2014 & 0.680 & 2.079 & 1.130 & 1.530 & 0.029 & 0.038 & $14.60 \%$ & $-0.90 \%$ \\
\hline 5 & 1885 & 0.834 & 1.999 & 1.141 & 1.606 & 0.060 & 0.071 & $21.60 \%$ & $1.20 \%$ \\
\hline 6 & 1380 & 0.995 & 1.912 & 1.168 & 1.712 & 0.090 & 0.086 & $18.80 \%$ & $2.30 \%$ \\
\hline 7 & 629 & 1.061 & 1.911 & 1.157 & 1.635 & 0.103 & 0.123 & $19.10 \%$ & $3.10 \%$ \\
\hline 8 & 115 & 1.058 & 2.075 & 1.173 & 1.836 & 0.119 & 0.112 & $19.60 \%$ & $0.90 \%$ \\
\hline All & 10134 & 0.573 & 1.823 & 1.133 & 1.541 & 0.036 & 0.047 & $14.40 \%$ & $-2.30 \%$ \\
\hline High $(6,7,8)$ & 2184 & 1.038 & 1.966 & 1.166 & 1.728 & 0.095 & 0.099 & $19.20 \%$ & $2.10 \%$ \\
\hline Low $(0,1)$ & 626 & -0.173 & 1.444 & 1.132 & 1.421 & -0.034 & -0.003 & $2.80 \%$ & $-10.30 \%$ \\
\hline High-Low & & 1.211 & 0.522 & 0.034 & 0.307 & 0.130 & 0.102 & $16.40 \%$ & $12.30 \%$ \\
\hline & & $* * *$ & $* * *$ & $* * *$ & $* * *$ & $* * *$ & $* * *$ & $* * *$ & $* * *$ \\
\hline
\end{tabular}

Note: Growth of earnings, GR_E $E_{t+k}$, is calculated as actual I/B/E/S EPS in period $t+k$ plus forgone earnings from dividends, divided by baseyear's forward earnings. Growth of sales, GR_S $S_{t+k}$, equals $S_{t+k} / S_{t+1}$ where $S_{t}$ is sales per share. Return Raw returns are calculated as the 24-month buy-and-hold returns, beginning August $1^{\text {st }}$ after portfolio formation. Size-adjusted returns equal raw returns subtract the returns for the same capitalization portfolio in the same period. Delisting returns are included. The differences are tested using the two-tailed Wilcoxon test. ***, **, * stand for being significant at $1 \%, 5 \%$, and $10 \%$, respectively.

\section{CONCLUSION}

The $\mathrm{P} / \mathrm{E}$ ratio has a crucial role in the investment community. This ratio reflects the market's expectation of future growth and firm risk (Chan et al., 2003; Wu, 2013). This ratio can be used to estimate cost of equity capital (Easton, 2004) and to earn excess stock returns from the glamour/value anomaly phenomenon (Basu, 1978). Financial analysts also widely cite the P/E ratio as a justification for their stock recommendations. This paper provides empirical evidence to the theoretical predictions in Ohlson and Zhan (2006) regarding the relation between the $\mathrm{P} / \mathrm{E}$ ratio and $\mathrm{ROE}$ and examines the future performance of firms with various $\mathrm{P} / \mathrm{E}$ ratios.

The results show that the P/E ratio has a U-shaped relation with ROE. Firms with higher forward P/E ratios achieve lower ROE in the subsequent years and the distribution of their realized ROE is more volatile and wide- 
spread than firms with lower forward P/E ratios. Using the GSCORE from Mohanram (2005), this paper separates winners from losers for high P/E firms. Among high P/E firms, firms with higher GSCORE report higher earnings growth, sales growth, and ROE in the subsequent two and five years than firms with lower GSCORE. Firms with higher GSCORE also yield excess returns than other firms.

This paper contributes to the research and investment communities by providing empirical evidence to the theoretical predictions of Ohlson and Zhan (2006). This paper also shows the future performance of firms with different P/E ratios. This paper demonstrates a way to separate winners from losers in high P/E firms. The findings give insights to investors regarding the outcomes to equity valuation and have implications for investment strategies.

\section{AUTHOR INFORMATION}

Wan-Ting (Alexandra) Wu is an Assistant Professor in the Department of Accounting and Finance at University of Massachusetts Boston. Her research interests are equity valuation, executive compensation, and analysts' forecasts. E-mail: wan-ting.wu@umb.edu

\section{REFERENCES}

1. Basu, S. (1977). Investment performance of common stocks in relation to their price-earnings ratios: A test of the efficient market hypothesis. The Journal of Finance, 32(3), 663-682.

2. $\quad$ Basu, S. (1983). The relation between earnings yield, market value, and return for NYSE stocks: Further evidence. Journal of Financial Economics, 12(1), 129-56.

3. Beaver, W., \& Morse, D. (1978). What determines price-earnings ratios? Financial Analysts Journal, 34(4), 65-76.

4. Bradshaw, M. (2002). The use of target prices to justify sell-side analysts' stock recommendations. Accounting Horizons, 16(1), 27-41.

5. Dechow, P., Hutton, A., \& Sloan, R. (1999). An empirical assessment of the residual income valuation model. Journal of Accounting \& Economics, 26(1-3), 1-34.

6. Fairfield, P. (1994), E/P, P/B and the present value of future dividends. Financial Analysts Journal, 50(4), 23-31.

7. Gode, D., \& Mohanram, P. (2003). Inferring the cost of capital using the Ohlson-Juettner model. Review of Accounting Studies, 8(4), 399-431.

8. Jaffe, J., Keim, D., \& Westerfield, R. (1989). Earnings yields, market values, and stock returns. Journal of Finance, 44(1), 135-48.

9. $\quad$ Kim, M., \& Ritter, J. (1999). Valuing IPOs. Journal of Financial Economics, 53(3), 409-437.

10. Liu, J., Nissim, D., \& Thomas, J. (2002). Equity valuation using multiples. Journal of Accounting Research, 40(1), 135-172.

11. Mohanram, P. (2005). Separating winners from losers among low book-to-market stocks using financial statement analysis. Review of Accounting Studies, 10(2-3), 133-170.

12. Ohlson J., \& Gao, Z. (2006). Earnings, earnings growth and value. Foundations and Trends in Accounting, $l(1)$.

13. Ou, J., \& Penman, S. (1989). Accounting measurement, price-earnings ratio, and the information content of security prices. Journal of Accounting Research, 27(Current studies on the information content of accounting earnings), 111-144.

14. Penman, S. (1996). The articulation of price-earnings ratios and market-to-book ratios and the evaluation of growth. Journal of Accounting Research, 34(2), 235-259.

15. Schreiner, A., \& Spremann, K. (2007). Multiples and their valuation accuracy in European equity markets. (Working paper). University of St. Gallen. Retrieved from http://papers.ssrn.com/sol3/papers.cfm?abstract_id=957352

16. Thomas, J., \& Zhang, H. (2006). Another look at E/P ratios. Yale School of Management. (Working paper). Retrieved from http://faculty.som.yale.edu/jakethomas/papers/smoothing.pdf

17. Wu, W. (2013). The forward E/P ratio and earnings growth. (Working paper). University of Massachusetts Boston. Retrieved from http://papers.ssrn.com/sol3/papers.cfm?abstract_id=1014177 
18. Yee, K. (2004). Forward versus trailing earnings in equity valuation. Review of Accounting Studies, 9(2-3), 301-329.

19. Zarowin, P. (1990). What determines earnings-price ratios: Revisited. Journal of Accounting, Auditing, and Finance, 5(2), 439-454. 


\section{APPENDIX}

\section{Definition of Main Variables}

\begin{tabular}{|l|l|}
\hline \multicolumn{1}{|c|}{ Variables } & \multicolumn{1}{c|}{ Calculation } \\
\hline$A D_{t}$ & Advertising expenses divided by average total assets \\
\hline$B M_{t}$ & $\begin{array}{l}\text { Book-to-market ratio = Common equity (adjusted for deferred tax liabilities) at the end of fiscal year } t-1, \\
\text { divided by market capitalization in April of each year } t\end{array}$ \\
\hline$C E X P_{t}$ & Capital expenditure = Capital expenditure divided by net property, plant, and equipment \\
\hline$F P E_{t}$ & $\begin{array}{l}\text { Forward price-to-earnings ratio }=\text { stock price measured in April of each year divided by Analysts' consensus } \\
\text { (median) one-year out EPS forecast, } E_{t+1}\end{array}$ \\
\hline$L E V_{t}$ & Leverage = Total assets divided by total common equity \\
$P A Y O U T_{t}$ & $\begin{array}{l}\text { Payout ratio. If earnings }>0 \text { then } P A Y O U T=\text { common dividend divided by earnings. If earnings }<=0 \text { then } \\
\text { items available for common equity. }\end{array}$ \\
\hline$R \& D_{t}$ & Research and development intensity = Research and development expense deflated by net sales \\
\hline$R O A_{t}$ & Income before extraordinary items divided by average total assets \\
\hline$R O E_{t}$ & Return on equity = Income before extraordinary items available for common equity divided by common equity \\
\hline$S I Z E_{t}$ & Market capitalization = number of common shares outstanding times stock price in fiscal year end \\
\hline$S T_{t}$ & Total sales \\
\hline$X F I N_{t}$ & External financing = (Change in total assets minus change in retained earnings) divided by total assets \\
\hline
\end{tabular}

